\title{
Peran Perempuan Berpendidikan Dalam Kesejahteraan Keluarga: Studi Kasus Di Desa Cukir Gg 1 Kecamatan Diwek Kabupaten Jombang
}

Siti Musyafaah ${ }^{1}$ Jasminto $^{2}$

${ }^{1,2}$ Program Studi Pendidikan Agama Islam, Universitas Hasyim Asy'ari, Indonesia

\begin{tabular}{l}
\hline Article Info \\
\hline Article history: \\
Received 2019-10-08 \\
Accepted 2020-03-10 \\
\end{tabular}

\section{Keywords:}

Perempuan

Pendidikan

Kesejahteraan Keluarga

\begin{abstract}
Perempuan adalah manusia yang mempunyai puki, dapat menstruasi, hamil, melahirkan anak, dan menyusui. Perempuan dalam agama mempunyai kedudukan yang sama.Perempuan juga mempunyai peran penting baik dalam keluarganya, masyarakat, dan agaman. Peran perempuan tidak bisa terlepas dari latar belakang pendidikan yang didapat oleh perempuan itu sendiri. Di mana pendidikan perempuan sangat berhubungan dengan hasil di mana peremuan tersebut berperan, baik di dalam keluarganya, masyarakatnya dan di lingkungan lainnya. Peran perempuan berpendidikan juga bisa membawa dampak positif dalam kesejahteraan keluarganya, baik dari segi ekonomi maupun non ekonomi. Fokus dalam penelitian ini adalah: 1) Peran perempuan berpendidikan di Desa Cukir Gg. 1,2) Kesejahteraan keluarga di Desa Cukir Gg. 1, 3) Peran perempuan berpendidikan dalam kesejahteraan keluarga di Desa Cukir Gg.1 Penelitian ini adalah jenis pendekatan kualitatif dengan studi kasus yang dilakukan di Desa Cukir Gg 1, di mana studi kasus penelitiannnya meneliti kehidupan nyata, melalui pengumpulan data yang detail dan mendalam yang melibatkan beragam sumber informasi yaitu: pengamatan, wawancara, dan dokumentasi.Berdasarkan penelitian tersebut bisa diketahui bahwa peran perempuan berpendidikan dalam kesejahteraan keluarga di Desa Cukir Gg 1 yaitu:1) peran perempuan mencari nafkah, di mana perempuan bekerja untuk memenuhi atau membantu perekonomian keluarganya, dan peran perempuan yang aktif dalam organisasi yaitu perempuan yang melakukan aktifitas di rumah juga mengikuti organisasi-organisasi yang ada di sekitarnya seperti Fatayat, PKK, dll. 2). Kesejahteraan keluarga di Desa Cukir yaitu banyaknya perempuan berpendidikan yang membantu ksejahteraan keluarganya dengan bekerja dan profesi yang beragam, berikut profesi perempuan berpendidikan di Desa Cukir Gg 1, diantaranya: Bekerja di Pabrik, pedagang, guru, dan bekerja di bidang kesehatan. 3) perempuan yang bekerja di luar rumah dan tetap menjalankan kewajiban di rumah yaitu perempuan yang bekerja atau aktif dalam organisasi, dan anak perempuan yang berpendidikan tinggi bekerja untuk membantu perekonomian keluarganya.
\end{abstract}

This is an open access article under the $\underline{C C B Y-S A}$ license.

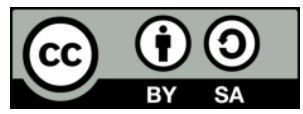

\section{Corresponding Author:}

Siti Musyafaah,

Program studi Pendidikan Agama Islam,

Universitas Hasyim Asy'ari,

Email: sitimusyafaah16@gmail.com

\section{PENDAHULUAN}

Allah SWT menciptakan manusia yaitu laki-laki dan perempuan yang berasal dari tanah. Artinya antara laki-laki dan perempuan memiliki kedudukan yang sama di hadapan Allah SWT. Secara jasmani tampak jelas perbedaan antara laki-laki dan perempuan. Mereka berbeda dari bentuk tubuh, besar dan kecinya, kuat dan lemahnya, dan dari pemikiran atau sudut pandangnya (Ratna Megawangi, 1999: 95). Selain itu laki- 
laki dan perempuan juga mempunyai perbedaan dalam perannya. Dalam sebuah keluarga peran laki-laki pada umumnya adalah sebagai kepala rumahtangga, yaitu mencari nafkah, menjadi pemimpin, menjadi contoh dan imam bagi istri dan anak-anaknya, sedangkan perempuan dalam keluarga berperan sebagai istri bagi suaminya dan ibu bagi anak-anaknya, mengasuh merawat, menyusui dan mendidik anak-anaknya. Walau demikian seiring berkembangnya zaman, peran-peran itu bergeser sesuai kondisi masing-masing keluarga. Ada sebagian perempuan yang menggantikan peran laki-laki yaitu peran mencari nafkah atau bahkan sebaliknya ada laki-laki yang menjalankan peran perempuan di rumah sebagai ibu rumah tangga yaitu memasak, mengasuh anak, membersihkan rumah, dll. Dari semua peran baik peran yang dilakoni laki-laki atau peran perempuan perlu memiliki bekal ilmu pengetahuan untuk menjalankan peran-peran tersebut dengan baik. Walaupun hanya berperan sebagai ibu rumah tangga saja. Yang kesehariannya di rumah memasak, membersihkan rumah dan yang terpenting adalah mengasuh dan mendidik anakanaknyalah yang perlu sekali dibekali ilmu pengetahuan. Karena mendidik anak bukanlah perkara yang mudah.

Peran perempuan di Desa Cukir Gg 1 sangat beragam, ada yang menjadi ibu rumah tangga saja, ada yang bekerja diluar rumah seperti menjadi pedagang di pasar, menjadi guru, petugas kesehatan, dll. Di mana peran-peran tersebut sangat berkaitan pula dengan latar belakang pendidikan mereka. Banyak perempuan berpendidika di Desa Cukir Gang 1 yang bisa menjalankan peran sebagai istri, ibu, dan juga pencari nafkah. Dengan kata lain perempuan hebat ini dapat menjalankan peran ganda peran mencari nafkah dan peran sebagaimana kodrat perempuan di rumahnya yaitu sebagai istri dan ibu bagi anakanaknya. Dari uraian di atas peneliti mencoba meneliti bagaimana peran perempuan berpendidikan di Desa Cukir Gang 1 dengan fokus penelitian: (1) Bagaimana peran perempuan berpendidikan di Desa Cukir Gang 1? (2) Bagaimana kesejahteraan keluarga di Desa Cukir Gang 1? (3) Bagaimana peran perempuan berpendidikan dalam kesejahteraan keluarga di Desa Cukir Gang 1 ?

Berdasarkan fokus masalah di atas peneliti menetapkan beberapa tujuan penelitian diantaranya: (1) Mendeskripsikan peran perempuan berpendidikan di Desa. Cukir Gg 1 Kec. Diwek Kab. Jombang, (2)Mendiskripsikan kesejahteraan keluarga di Desa. Cukir Gg 1 Kec. Diwek Kab. Jombang, (3) Mendeskripsikan peran perempuan berpendidikan dalam kesejahteraan keluarga di Desa. Cukir Gg 1 Kec. Diwek Kab. Jombang. Peran adalah Kedudukan seseorang yang diharapkan pada seseorang sesuai dengan keahliannya, sesuai dengan porsinya dengan mengharapkan hasil yang maksimal. Perempuan adalah manusia yang yang mengandung, melahirkan, menyusui, mengasuh dan merawat anak, mempunyai sifat yang lemah lembut dari pada laki-laki. (DEPDIKNAS, 2002). Perempuan adalah sosok manusia yang di ciptakan Allah dengan kemuliaaan, yang dihormati, dan diperhatikan oleh laki-laki. Perempuan yang baik yang menyenangkan hati, menyejukkan mata dalam agama di sebut dengan perempuan yang shalihah, perempuan yang berharga lebih dari emas atau perhiasan dunia lainnya.(Ya'qub Chamidi, SS, 2011).

Berbicara soal peran perempuan pasti juga berhubungan dengan latar belakang pendidikan perempuan itu sendiri yang mana dapat menjadi bekal, menjadi dasar pengetahuan, pengalamannya dalam menjalankan perannya. Secara istilah, banyak para ahli telah memberikan difinisi mengenai kata pendidikan. Diantara definisi tentang pendidikan adalah proses pembentukan karakter seseorang, mengarahkan emosi seseorang kearah yang lebih baik. Dalam arti lain kehidupan adalah pendidikan dan pendidikan adala kehidupan. .( Moh. Haitami Salim, 2013). Kebanyakan perempuan berpendidikan tentu memiliki peran yang penting dalam keluarganya, masyarakat sekitarnya dan bahkan di Negara. Dalam keluarga perempuan berpendidikan dapat menunjang kesejahteraan keluarganya baik kesejahteraan ekonomi maupun non ekonomi. Keluarga sejahtera adalah keluarga yang terdiri dari dua orang atau lebih di mana terdiri dari suami dan istri yang terjalin dari perkawinan yang sah yang diakui oleh agama dan negara, mampu memenuhi kebutuhan hidup baik secara spiritual dan materi yang layak dan kecukupan, memiliki pandangan dan tujuan yang sama sehingga tercapai kehidupan yang rukun bersosial dengan masyarakat sekitarnya. (Dalam Peraturan RI No.21, 1994)

\section{METODE}

Penelitian ini adalah jenis pendekatan kualitatif deskriptif yaitu, penelitian yang bertujuan untuk memahami tentang keadaan yang dialami oleh pelaku penelitian, misalnya perilaku sudut pandang seseorang, motivasi atau alasan seseorang, tindakan yang diambil dengan cara menjelaskan dalam bentuk kata-kata dan bahasa sesuai dengan apa yang dialami dengan memanfaatkan berbagai metode almiah. (Lexy J. Moleong, 2010). Jenis penelitian ini adalah studi kasus (case study). Penelitian studi kasus dengan pendekatan kualitatif yang meneliti kehidupan nyata, dengan terbatas kasus melalui pengumpulan data yang terperinci dan mendalam yang melibatkan beragam sumber informasi yaitu pengamatan, wawancara, bahan audiovisual, dokumen dan berbagai laporan sesuai dengan kasus yang diteliti. (Jhon W, Creswell, 2015). Dalam penelitian ini yang menjadi alat penelitian adalah peneliti itu sendiri (human instrument). Peneliti sebagai alat penelitian harus melakukan validasi seberapa jauh peneliti siap melakukan penelitian, melalui evaluasi diri seberapa jauh pemahaman terhadap masalah yang akan diteliti serta kesiapan dan bekal 
memasuki lapangan penelitian. Peneliti disini sebagai alat penelitian yaitu sebagai orang yang melakukan penelitian secara langsung, mendokumentasikan hasil penelitian dan mewawancarai respondenya secara langsung. Oleh karena itu, peneliti terjun langsung ke lapangan (tempat yang diteliti) sehingga tidak ada jarak dengan responden yang diamati dan kehadirannya diakui.

Hasil penelitian ini didapat dari dua jenis sumber data, yaitu data primer dan data sekunder. Data primer yaitu data yang didapatkan di lapangan yang bersumber dari narasumber atau orang yang bersangkutan dengan penelitian yang diperoleh secara langsung melalui wawancara. Sedangkan data sekunder yang diperoleh berupa dokumentasi yang diperoleh dari hasil penelitian yang dilakukan, dan buku-buku ilmiah yang berkaitan dengan penelitian. Uji keabsahan dalam penelitian ini meliputi (1) Uji keperayaan terhadap data hasil penelitian yang dilakukan dengan melakukan penelitian dengan waktu yang lama, ketekunan, triangulasi, diskusi dengan teman sejawat bahkan dengan orang-orang yang lebih berpengalaman dari sipeneliti.(2) menerapkan hasil penelitian pada sekelompok masyarakat atau populasi di mana penelitian itu dilakukan (3) Uji obyektifitas yaitu apabila hasil dari penelitian telah disepakati banyak orang.

\section{HASIL DAN PEMBAHASAN}

Kemajuan zaman menuntut seseorang untuk menjadi manusia yang bisa menguasai dunia, mengikuti perkembangan zaman dan salah satu jembatannya adalah dengan pendidikan. walaupun pendidikan atau mencari ilmu atau pengalaman tidaklah harus di bangku sekolah atau di tempat formal lainnya seperti pesantren. Pendidikan adalah salah satu jembatan seseorang untuk dapat mengikuti majunya teknologi, dan perkembangan zaman saat ini. Bagaimana tidak dalam pendidikan seseorang akan dapat mengenal dan mengetahui banyak ilmu-ilmu baru. Sekolah salah satu tempat yang dikenal oleh kebanyakan orang sebagai tempat untuk pendidikan, tempat untuk menuntut ilmu dan menambah pengalaman. Menuntut ilmu bagi seriap orang adalah suatu kewajiban. Baik laki-laki maupun perempuan wajib menuntut ilmu, wajib berpendidikan. Bahkan di Indonesia sudah ada peraturan di mana setiap warga negara wajib berpendidikan atau sekolah minimal 12 tahun. Hal ini menunjukkan bahwa pendidikan sangat penting bagi setiap orang. Tidak tebang pilih laki-laki atau perempuan memiliki kewajiban dan kesempatan yang sama untuk mengampu pendidikan di sekolah sampai tingkat SMA minimal. Pemerintah juga mendukung pendidikan dengan banyaknya bantuan-bantuan bagi masyarakat miskin atau menengah ke bawah agar dapat melaksanakan wajib belajar 12 tahun.

Kemajuan zaman menuntut seseorang untuk menjadi manusia yang bisa menguasai dunia, mengikuti perkembangan zaman dan salah satu jembatannya adalah pendidikan. Walaupun pendidikan atau mencari ilmu atau pengalaman tidaklah harus di bangku sekolah atau di tempat formal lainnya. Berbicara soal pendidikan, di Desa Cukir Gg 1 Kecamatan Diwek Kabupaten Jombang masih ada sebagian perempuan yang memiliki latar belakang pendidikan yang kurang walaupun sudah didukung dengan lingkungan yang ada, di dukung dengan program-progam bantuan dari pemerintah walaupun masih banyak kasus di mana banyak bantuan yang salah sasaran. Dengan alasan utamanya adalah ekonomi menjadikan orangtua tidak memberikan kesempatan anak-anaknya terutama anak perempuannya untuk mengampu pendidikan tinggi hingga tingkat sarjana. Kebanyakan lulusan SMA bahkan masih ada yang hanya lulusan SMP. Perempuan berpendidikan dalam perannya sangatlah berpegaruh bagi kehidupan di sekitarnya, baik dalam keluarganya, masyarakatnya hingga negara, oleh karena tidak sedikit pula perempuan-perempuan berpendidikan yang lebih sukses dari pada laki-laki. Di Desa Cukir Gg 1 kecamatan Diwek Kabupaten Jombang ini belum banyak perempuan-perempuan yang berpendidikan tinggi di atas SMA entah itu D1, D2, D3, S1, S2, S3. Ada beberapa perempuan di Desa Cukir Gg 1 yang lulusan D1, D2, D3, S1, dan S2 di mana mereka berperan menjadi ibu rumahtangga, dan ada yang bekerja di luar rumah.

Desa Cukir Gg 1 Kecamatan Diwek Kabupaten Jombang yang letaknya sangat strategis dengan dikelilingi oleh lembaga-lembaga pendidikan dari tingkat terendah hingga tertinggi seharusnya bisa menjadikan motivasi bagi penduduknya untuk berpendidikan tinggi. Berikut ini adalah peran perempuan berpendidikan di Desa Cukir Gg 1: Pertama, Peran Perempuan berpendidikan di luar rumah yaitu: peran perempuan yang bekerja di luar rumah/ mencari nafkah dan peran perempuan yang aktif dalam organisasi atau kegiatan sosial. Ada dua alasan perempuan bekerja yakni: Kondisi ekonomi yang kurang, artinya mereka bekerja karena kondisi ekonomi rumah tangga yang rendah, sehingga bekerja dirasa dapat meningkatkan ekonomi rumah tangga menjadikan bekerja atau mencari uang adalah suatu keharusan suatu hal sangat penting. Selain itu alasan perempuan bekerja atau mencari nafkah adalah mengisi waktu. Banyak para perempuan yang terlihat hidup berkecukupan dari hasil kerja suaminya namun masih juga bekerja atau mencari nafkah. Ternyata alasan mereka bekerja adalah bentuk bersosial saja, untuk mencari kegiatan di luar rumah agar tidak merasa jenuh di rumah. Biasanya hal ini terjadi pada keluarga yang ekonominya tinggkat menengah ke atas. Mereka bekerja bukan semata-mata bertujuan untuk mencari tambahan dana untuk ekonomi keluarga tapi merupakan salah satu bentuk aktualisasi diri mencari wadah atau tempat untuk bersosialisasi

Siti Musyafaah (Peran Perempuan Berpendidikan Dalam Kesejahteraan Keluarga...) 
Kedua, perempuan berpendidikan di dalam rumah. Ada dua peran perempuan berpendidikan di dalam rumah yaitu perempuan sebagai ibu dan peran perempuan sebagai istri. Peran perempuan sebagai ibu rumah tangga dalam keluarga yaitu perempuan yang hamil, melahirkan, menyusui, mengasuh, merawat, memelihara, melindungi dan mendidik anak-anaknya. Selain sebagai ibu di rumah seorang perempuan juga berperan sebagai istri. Yaitu peran yang tidak kalah penting dari peran seorang ibu. Sebagai istri, perempuan harus melayani suami baik dari makanan, pakaian hingga tidurnya. Hampir kebanyakan laki-laki mendambakan seorang istri yang sholihah yaitu istri yang menyejukkan hati, menyejukkan mata, dapat menjaga kehormatan suaminya dan menjadi ibu yang baik bagi anak-anaknya karena sebaik- baik perhiasan dunia adalah perempuan yang shalihah.

Potensi lapangan pekerjaan di Desa Cukir sebenarnya sudah sangat banyak, sehingga masyaraka dapat meningkatkan taraf hidupnya. Seperi luasnya area persawahan yang masih ada, industri pabrik yang ada di sekitar desa seperti pabrik gula Cukir, Pabrik Tahu, Pabrik Plastik dan juga banyaknya peluang perdagangan yang ada disekitar karena dekat dengan Pasar dan jalan raya ditambah dengan wisata religi makam Gus Dur yang sudah di kenal oleh nasional bahkan internasional. Tapi kenyataannya hal ini tidak menjadi jaminan kesejahteraan keluarga di Desa Cukir Gg 1. Banyak dari masyarakatnya yang bekerja di luar kota Jombang, bahkan bekerja ke Luar jawa. Pada kenyataannya kesejahteraan keluarga tidak dapat dipukul rata dan setiap orang memiliki sudut pandang masing-masing tentang kesejahteraan keluarga mereka, karena hal itu hanya bisa dirasakan oleh anggota keluarga itu sendiri. Ada orang yang berpendapat bahwa kesejahteraan keluarga diukur dari ketentraman keluarganya, memiliki anak, rumah walau kecil, kesehatan dan sebagainya. Namun ada pula yangyang berpandangan bahwa kesejahteraan keluarga di ukur dari segi ekonominya, yaitu pekerjaan yang mapan, pendidikan yang tinggi, rumah yang besar, dll. Di sini penulis menekankan dan mengukur tingkat kesejahteraan hidup keluarga dari segi ekonominya yang didukung dengan pendidikan. Oleh karena itu penulis akan menjabarkan bagaimana perempuan-perempuan berpendidikan di Desa Cukir Gg 1 yang membantu untuk mencapai kesejahteraan keluarganya dari segi ekonomi, diantaranya: Pertama, Perempuan Pekerja di Sektor Industri (Pabrik). Banyak generasi muda sekarang yang sudah memilki pandangan maju, di mana mereka menentukan kelangsungan hidupnya setelah lulus sekolah. Ada yang melanjutkan pendidikan sampai tingkat tertinggi, ada yang bekerja bahkan ada yang menjadi pengusaha dengan menciptakan lapangan pekerjaan bagi banyak orang. Bekerja di pabrik juga salah satu pandangan bagi sebagian pemuda dengan memiliki posisi yang baik, yang tinggi dengan gaji yang besar. Perempuan di Desa Cukir ada yang bekerja di pabrik. Namun kebanyakan mereka hanya menjadi buruh pabrik dengan gaji yang kecil, jam kerja dari pagi sampai sore. Ada pula sedikit perempuan di Desa Cukir Gg 1 yang bekerja di pabrik dengan jabatan yang tinggi dan gaji yang tinggi pula. Sehingga kesempatan mereka untuk mensejahterakan keluarganya atau membantu perekonomian keluarganya kea rah yang lebih baik pun terbuka lebar. Hal ini dikarenakan latar belakang pendidikan mereka yang berbeda. Karena pada sector industry tentu memerlukan ijazah yang memadai yang sesuai dengan keahliannya agar tercapai hasil yang maksimal, sehingga menjadikan pabrik tidak mengalami kerugian dengan mengambil mereka sebagai karyawan atau anggota dari pabriknya.

Kedua, Perempuan Pedagang. Berdagang adalah salah satu profesi yang sudah banyak di geluti oleh masyarakat indonesia. Selain itu berdagang sudah ada sejak zaman Rasulullah, beliau memberikan contoh sifat-sifat bergadang yang harus dicontoh oleh para pedagang. Yaitu kejujurannya, bagaimana seseorang pedagang yang berdagang dengan jujur, memberikan harga yang sama antara satu pembeli dengan pembeli lainnya, memberikan barang dagangan yang bagus, yang pantas untuk dijual. Tidak menjual barang yang rusak dan yang tidak kalah penting adalah menjual barang-barang yang halal. Yang diperoleh dengan caracara yang halal pula. Sehingga menjadikan keberkahan bagi keluarganya.

Desa Cukir Gg 1 banyak para perempuan yang berprofesi sebagai seorang pedagang. Ada yang berdagang makanan, minuman, baju, dll. Mereka menjual di pasar Cukir, di Depan Rumah, da nada pula yang berdagang di Kawasan Makam Gus Dur. Tapi kebanyakan dari perempuan berpendidikan di Desa Cukir berdagang hanya sebagai kegiatan sampingan, bukan sebagai profesi utamanya. Namun demikian berdagang juga bisa dikatakan sebagai profesi yang sangat membantu kesejahteraan keluarga, karena tempat dagang yang tidak jauh dari rumah mereka menjadikan semua menjadi lebih muda untuk dilakukan.

Ketiga, Perempuan Sebagai Tenaga Pendidik (Guru). Perempuan adalah gudang ilmu, pusat peradaban bagi anak-anaknya maka sangat perlu bahkan harus bagi perempuan untuk berpendidikan. Hal ini menjadikan salah kaprah apabila masih ada orang yang beranggapan bahwa untuk menjadi ibu tidak butuh pendidikan yang tinggi, karena mereka beranggapan profesi ibu adalah profesi yang muda, profesi yang sudah lumrah, profesi yang menjadi kodrat setiap perempuan sehingga setiap perempuan pasti mampu, pasti bisa menjalani profesi ini walau tanpa pendidikan yang tinggi. Profesi pendidik atau guru banyak diambil oleh para perempuan berpendidikan di Desa Cukir Gg 1. Selain dari rutinitas dan kewajiban mereka sebagai seorang ibu di rumah yang harus mendidik anak-anak mereka, mereka juga memilih menjadi seorang pendidik di sebuah lembaga pendidikan dengan tujuan mencerdaskan anak bangsa, dan mengamalkan ilmu yang mereka dapat di bangku sekolah. 
Keempat, Bekerja di Bidang Kesehatan. Di Desa Cukir ternyata ada juga perempuan yang mengambil pendidikan tinggi dengan latar belakang dunia kesehatan, yang mana profesi ini juga sangat bermanfaat bagi masyarakat. Peran perempuan berpendidikan dalam kesejahteraan keluarga di Desa Cukir tentu sangat membantu, dan sangat berpengaruh bagi kehidupan dan kesejahteraan keluarganya baik dalam segi ekonomi maupun non ekonomi. Begitu pula dalam karir yang mana condong pada perempuan yang bekerja mencari nafkah untuk menambah penghasilan dan pendapatan ekonomi keluarganya tentu saja memiliki karir yang lebih bagus yang lebih terhormat.

Banyak profesi yang sekarang ini memerlukan ijazah yang sesuai dengan tempatnya, atau bidangnya masing-masing. Profesi yang biasanya menggunakan ijazah merupakan bukan profesi sembarangan, seperti profesi dokter, perawat, apoteker, bidan, dan profesi lainnya di bidang kesehatan. Tidak mungkin ijazah S1 pendidikan akan diterima di bidang kesehatan sebagai perawat sekalipun, begittu pula sebaliknya. Di Desa Cukir Gg 1 ada sebagian perempuan berpendidikan yang berprofesi dalam bidang kesehatan, ada yang sebagai bidan, farmasi, dan dokter special kandungan. Pada dasarnya semua profesi adalah mulia dan sangat bermanfaat bagi kehidupan, asalkan profesi tu bertujuan dan berniat untuk kebaikan. Tidak melanggar aturan agama, moral dan norma-norma masyarakat sekitar.

\section{KESIMPULAN}

Berdaarkan dari pemaparan di atas, dapat diperoleh kesimpulan bahwa peran perempuan berpendidkan di Desa Cukir Gg 1 adal dua yaitu, peran perempuan mencari nafkah, di mana perempuan bekerja di luar rumah untuk memenuhi atau membantu perekonomian keluarganya dan peran perempuan aktif dalam organisasi yaitu seorang perempuan yang selain melakukan aktifitas di rumah juga mengikuti organisasiorganisasi yang ada di sekitar seperti, Fatayat NU, PKK, dll. Kesejahteraan Keluarga di Desa Cukir, banyak perempuan yang membantu kesejahteraan keluarganya dengan bekerja atau dengan profesi yang beragam, berikut profesi perempuan berpendidikan di Desa Cukir Gg 1, diantaranya: Bekerja di Pabrik, pedagang, guru, dan bekerja di bidang kessehatan. Peran Perempuan Berpendidikan dalam Kesejahteraan Keluarga di Desa Cukir Gg 1 yaitu perempuan yang bekerja di luar rumah dan tetap menjalankan kewajiban di rumah yaitu perempuan yang bekerja atau perempuan yang aktif dalam organisasi tapi masih menjalankan kewajibannya di rumah, mengerjakan pekerjaan rumah sebagaimana para ibu atau para perempuan umumnya, dan anak perempuan yang berpendidikan tinggi bekerja untuk membantu perekonomian keluarganya yaitu seorang anak yang berpendidikan tinggi S1 mereka setelah lulus dari sekolah atau universitasnya mengambil keputusan untuk bekerja baik dengan alasan membantu perekonomian keluarganya.

\section{REFERENSI}

Chamidi, Ya’qub. Menjadi Wanita Shalihah \& Mempesoa. Mitrapress. 2011

Creswell, Jhon W. Penelitian Kualitatif \& Desain Riset Memilih Diantara Lima Pendekatan, Yogyakarta: Pustaka Pelajar, 2015.16

Departemen Pendidikan Nasional. Kamus Besar Bahasa Indonesia. Jakarta: Balai Pustaka. 2

Megawangi, Ratna. Membiarkan Berbeda?,Sudut Pandang Baru Tentang Relasi Gender. Bandung: Penerbit Mizan Anggota IKAPI. 1999002

Moleong, Lexy J. Metodologi Penelitian Kualitatif, Bandung: Remaja Rosdakarya, 2016.

Salim, Moh. Haitami. Pendidikan Agama dalam Keluarga. Jogjakarta: Ar-Ruzz Media. 2013

Sugiyono, Metode Penelitian Kuantitatif, Kualitatif dan R\&D, Bandung: Alfabeta, 20 